\title{
Developing entrepreneurship training curriculum based on Tawhidic paradigm and legal principles: A case study of Malaysia
}

\author{
Farah Akmar Anor Salim * , Ainul Jaria Maidin **(D), \\ Suhaimi Mhd Sarif*(D), Dolhadi Zainudin* \\ * Kulliyah of Economics and Management Sciences, International Islamic University Malaysia \\ ** Ahmad Ibrahim Kulliyyah of Laws, International Islamic University Malaysia
}

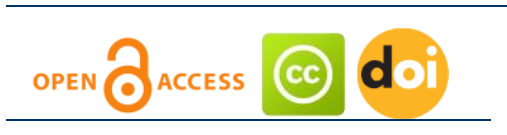

Article history:

Received: April 16, 2019

1st Revision: June 20, 2019

Accepted: November 16, 2019

\section{JEL classification:}

L26

053

DOI:

10.14254/jems.2019.4-2.3
Abstract: The importance of legal literacy in conducting business dealings has long been argued by the academics. Besides aiming for profit, entrepreneurial activities are important in meeting the social obligations of the government to ensure the development of a resilient economy. Business schools are required to promote integrated curriculum to ensure entrepreneurs will not only be able to identify business opportunities supported by required management skills. The integrated curriculum besides providing students with the ability to comprehend the key business disciplines will also need to nurture the humanistic skills, ethics and values. The incorporation of these elements will help create entrepreneurs with civic-mindedness, excellent interpersonal communication and leadership skills as well as be resilient. This paper singles out the ideology in promoting integrated curriculum for entrepreneurs training in the Malaysian context particularly the importance of inculcating legal knowledge to ensure the entrepreneurs will manage their activities within the permitted limits of the Malaysian law and global requirements. A comprehensive set of questionnaire containing 68 questions were administered to 543 entrepreneurs using convenience sampling. The rational of the practice of selecting local entrepreneurs as a sample for the study is to obtain their opinions on the relevant skills needed in managing their business. This can help identify aspects that can be incorporated to improve the current entrepreneur's training curriculum. The survey revealed that inculcating Islamic principles and ethics in entrepreneur's activities can increase their credibility in conducting business with others besides 
being resilient in developing the business (concept of taqwa). The study provides significant information to the academic and business community including private corporations and governments on the essential elements that need to be incorporated in conducting business. Finally, the study concludes with proposing the important aspects to be incorporated in the entrepreneurs training curriculum in Malaysia specifically the Muslim world in general.

Keywords: entrepreneur, Tawhidic paradigm, curriculum, legal knowledge, entrepreneurship.

\section{Introduction}

Research on entrepreneur is increasing in line with the economic development across the globe. Engendering into the entrepreneurial activities is becoming a prominent goal for many countries as it provides beneficiary rewards to the national income.

Realizing the important of the entrepreneurial field, several agendas are develop to achieve greater level of success. Among the activities involved is to promote their educational and training opportunities to sharpen their skills and abilities, specifically in business dealing (Cooney, 2012).

An integrated curriculum for entrepreneurship in today's curriculum strives to nurture entrepreneurs in identifying business opportunities and sharpen their personal skills. The corporation of these components not only creates entrepreneurs with excellent interpersonal skills and sharpen their communication and leadership talent but rather to hone them with high civic mindedness (Weber \& Englehart, 2011). This paper singles out an evocation to nurture students with greater practices of Islamic principles and legal knowledge.

\section{Literature review}

Entrepreneur's education received plethora of research over the last few decades by many researchers, academicians and practitioners (Kozlinska, 2011). Most of the fields emphasize increasing the quality standards of entrepreneur's education system. In responding to this agenda, higher institutions including universities and professional training providers have been greatly refocusing on the existing curriculum to encounter the challenges to upgrade entrepreneurship module. This includes the notion of involving the students onto the field to experience the situation.

The most component that is greatly highlighted in the existing curriculum is the need to acquire entrepreneur's knowledge on legislative matters (Pache \& Chowdhury, 2012). Reason being, the demonstration of law and legislative in the development of entrepreneurship is imperative. This has been proven by the preliminary researcher that the successful conduct of business requires knowledge and adherence to prescribed legislation (Serafimovska, 2014). Among the knowledge includes the rules and regulations of taxation, insurance, civil and criminal liability. However, legal regulations to the entrepreneurial world are not restricted to the static concept, but rather it depends on the business's feature of dynamism, such as threats or opportunities.

Another reinforcement of legislation to entrepreneur activities is to reinforce criminal laws as regards to bribery and corruption in every substance. This includes, criminal offences, which prosecute not only individuals but also companies. It is therefore crucial to include courses on legislative issues in entrepreneurship curriculum to make students better understand compliance with the existing legal framework and ethical standards.

\section{Integrated entrepreneur's curriculum}

Entrepreneur's curriculum at present plays an important role in the process of building entrepreneurial capacity. Besides nurturing students to sharpen their entrepreneurial skills, the underline of government policies and procedures in managing business is another essential element that should be included in the curriculum. Henceforth, entrepreneur's curriculum comprises of a complete set of content that emphasizes the interrelationships between business functional areas and the overall understanding of business operation. 
The juxtaposition of current entrepreneurial studies integrates key business disciplines and holistic view. The intention does not only aims to improvise entrepreneur's education programs continuously, but rather to ensure that the student gains values, knowledge and abilities to make a difference (Weber, 2014). Studies in entrepreneurial and Islamic practices have regained the attention from many academicians and practitioners at present (Tlaiss 2014; Al Idrus 2013; Hunter 2014; Gümüsay 2014). In this regards, the study area highlighted the rules to guide and sustain businesses productivity and growth.

\section{Tawhidic paradigm}

'Tawhidic' reflects the whole aspects of human intellectual process in everything they involve and deals with (Choudhury, 2014). The philosophy explains the conception of human wellbeing that involve both intra-systems and inter-systems across human behaviour. In short, the ideology of Tawhid comprehends the whole set of belief and attribute in God including its primordial existence and absoluteness.

The term 'paradigm', on the other hand, refers to a pattern of scientific thinking on the truth through various observations and experiments (Choudhury, 2014; Rengiah, 2013; Suhaimi \& Sarif, 2011; Mhd Sarif \& Sarwar, 2014). This is significant in the academic context as it is the first methodological issue that needs to be addressed especially in the research world (McMurray, 2009).

In the Islamic civilization, all constituents in human life and its nature are bound together and become integrated. This includes the set of their belief systems, values and morality, the spirit and matter of all creatures, culture, society, politics and economy (Yousuf, 2006). These practices incorporated the principle in attaining benefits not only in the world (Al-Duniya) but also in the hereafter (al-Akhirah). As such, these conceptions explained the fundamental aspects of Tawhidic paradigm.

\section{Malaysian philosophy in Islamic education}

The curriculum system in Malaysia contains issues on philosophical, historical, psychological and social foundations (Hashim, 2014). The fundamental courses contain syllabus that reflect values, perception and knowledge to nurture the students in achieving the target and goal.

In relation with entrepreneurial education system in Malaysia, the manifestation of Islamic values is particularly significant. The government has promoted Islamic principles to regulate its education system through the practice of contemporary conventional knowledge (Hashim, 2014a). In this regards, student's actions, skills and activities are linked to the Islamic tradition and practices. Therefore, the fundamental issues relates with the spiritual aspects harmonize with the concept of practicing goodwill in life.

Another important feature that triggers entrepreneurs' business endeavors besides skills and ethics is legal constituent. These are proven when Cooney (2012) demonstrated that that entrepreneurs with greater skills but ignore legal aspects and violate legal enforcement perform imbalanced business activities. Entrepreneurs are required to fulfil social obligation, which are affirmed through the national's legal constituent.

\section{Research problem}

While entrepreneur's integrated curriculum contains topic that emphasize on entrepreneurial knowledge, such as business procedures, managerial skills and legislation aspects, the syllabus also comprises of entrepreneurial judgment embracing the moral codes and principles. Hence, these elements cover both secular and spiritual aspects that help to nurture entrepreneur in managing and organizing business.

However, although integrated curriculum for entrepreneur covers every notion of entrepreneurial principles, the unprincipled trade and disobedient issues against morals and creed are still rampant in business settings (Becker, Hauser \& Kronthaler, 2013). According to Bash (2015), the rationale is due to the fact that the syllabus centers on ethical attitudes rather than ethical behavior. That is, the focus is more on entrepreneur's judgment, but not on their actions when facing difficult situations.

Considering the lack of holistic approach in complementing entrepreneurs' endeavors, the guiding index in measuring ethical compliance is necessary. This is to gauge entrepreneur's principles in secular activities and incorporate it with the spiritual aspects. Gümüsay (2014) claimed that the integration of the existing theories and practices with religious aspects is vital in 
creating competent entrepreneurs. Therefore, attentiveness in measuring entrepreneurs' proficiency in triggering their inner strength and willpower is essential.

Due to the paucity of empirical research on entrepreneurial undertakings through integrated curriculum especially in legislative approach towards Malaysian entrepreneurs, this study scrutinizes the content and compares it with the holistic factor through the Islamic concept from the Tawhidic paradigm.

\section{Research methodology}

This study is interested in establishing entrepreneur's curriculum imbues with legal knowledge and an Islamic work related ethical values and practices. Given the need to explore the reality of Malaysian entrepreneur on the values and skills perceived, the study has adopted quantitative approach for data collection and analysis.

Self-administered data were collected from the sample of 543 Malaysian entrepreneurs from numerous business backgrounds and experiences. The survey instrument comprised demographic information with rating scale items (5-point Likert scale) and open-ended questions.

To test the principle component methods, the study extracted three factors from factor analysis and labeled as legal knowledge, Tawhidic paradigm and resilient entrepreneur. Table 1 Reliability Statistics shows the Cronbach alpha values of all three factors, namely; legal knowledge, Tawhidic paradigm and resilient entrepreneur; of which each results shows $0.731, .892$ and .708 simultaneously. According to Hair (1995), the acceptable alpha is preferably higher than 0.7. Therefore, it is concluded that the reliability of construct for all three factors is acceptable threshold.

\begin{tabular}{|c|c|c|c|}
\hline Factor & Cronbach's Alpha & $\begin{array}{c}\text { Cronbach's Alpha Based on } \\
\text { Standardized Items }\end{array}$ & $\mathrm{N}$ of Items \\
\hline Tawhidic Paradigm & .892 & .894 & 8 \\
\hline Resilient Entrepreneur & .708 & .711 & 4 \\
\hline
\end{tabular}

\section{Findings}

The findings from the study are divided into three:

i. Descriptive statistics of demographic information;

ii. Exploratory Factor Analysis (EFA);

iii. Confirmatory Factor Analysis (CFA);

iv. Predictors of Tawhidic Paradigm; and

v. Mediation factors in resilient entrepreneurs.

\section{i. Descriptive statistics of demographic information}

A total of 720 questionnaires were distributed to entrepreneurs in the Malaysian region, with different backgrounds and ethnicities, of which 543 were returned competed, yielding $75.42 \%$ response rate. The sample of the study were from both gender with high percentage on man compared with women (57.1\%; 310/543), with the highest range of age between $41-45$ years (24.7\%; 134.543), followed by $46-50$ years $(20.8 \% ; 113)$ and $36-40$ years $(18.8 \% ; 102)$. Majority of the respondents are from Malay ethic group followed by Chinese and Baba \& Nyonya respectively $(45.5 \% ; 20.1 \% ; 11.6 \%)$.

Most of the respondents in this study are from urban which 337 (62.1\%) with married status $341(62.8 \%)$ and deals in a trading business sector $(17.7 \%)$. With respect to the educational level, majority of the respondents possessed bachelor's degree with 30.4\% (164/543), compared with $21.2 \%(115 / 543)$ to those with secondary school's qualification and professional levels with a total of $19.7 \%$ respondent (103/543). Table 2 below demonstrated the differences in demographic factors ranges from gender, age and ethic group respectively. 


\begin{tabular}{|c|c|c|}
\hline Demographic Respondent & & Frequency [\%] \\
\hline \multirow[t]{2}{*}{ Gender } & Male & $310[57.1]$ \\
\hline & Female & $233[42.9]$ \\
\hline \multirow[t]{8}{*}{ Age } & $<25$ & $4[0.7]$ \\
\hline & $26-30$ & $28[5.2]$ \\
\hline & $31-35$ & $31[5.7]$ \\
\hline & $36-40$ & $102[18.8]$ \\
\hline & $41-45$ & $134[24.7]$ \\
\hline & $46-50$ & $113[20.8]$ \\
\hline & $51-55$ & $88[16.2]$ \\
\hline & $>55$ & $43[7.9]$ \\
\hline \multirow[t]{8}{*}{ Ethnic Group } & Malay & $247[45.5]$ \\
\hline & Indian & $43[7.9]$ \\
\hline & Chinese & $109[20.1]$ \\
\hline & Baba \& Nyonya & $63[11.6]$ \\
\hline & Singh & $33[6.1]$ \\
\hline & Iban & $20[3.7]$ \\
\hline & Kadazandusun & $23[4.2]$ \\
\hline & Bajau & $5[0.9]$ \\
\hline \multirow[t]{2}{*}{ Origin } & Rural & $206[37.9]$ \\
\hline & Urban & $337[62.1]$ \\
\hline \multirow[t]{2}{*}{ Marital Status } & Married & $341[62.8]$ \\
\hline & Not Married & $202[37.2]$ \\
\hline \multirow[t]{6}{*}{ Education Level } & Primary school & $42[7.7]$ \\
\hline & Secondary school & $115[21.2]$ \\
\hline & Undergraduate & $165[30.4]$ \\
\hline & Postgraduate & $103[19.0]$ \\
\hline & Professional & $107[19.7]$ \\
\hline & None & $11[2.0]$ \\
\hline \multirow[t]{17}{*}{ Business Sector } & Trading & $96[17.7]$ \\
\hline & Education & $23[4.2]$ \\
\hline & Services & $85[15.7]$ \\
\hline & Finance/Insurance & $37[6.8]$ \\
\hline & Hospitality & $21[3.9]$ \\
\hline & Transportation & $16[2.9]$ \\
\hline & Food and Beverages & $59[10.9]$ \\
\hline & Fabrication & $17[3.1]$ \\
\hline & Marine & $2[0.4]$ \\
\hline & Health-care & $29[5.3]$ \\
\hline & Manufacturing & $13[2.4]$ \\
\hline & Construction & $18[3.3]$ \\
\hline & Agriculture & $25[4.6]$ \\
\hline & Retailing & $12[2.2]$ \\
\hline & Mining & $43[7.9]$ \\
\hline & Wholesaler & $8[1.5]$ \\
\hline & Sport & $3.9[7.2]$ \\
\hline
\end{tabular}

Note. $\mathrm{N}=543$

\section{ii. Exploratory Factor Analysis (EFA)}

The study carries out a factor analysis with varimax rotation to validate whether the respondents perceived the four constructs, namely, legal knowledge, core values, roles \& duties and resilient entrepreneur. The results showed four-factor solution and the total variance explained was 69.767 percent of the total variance. The result suggests that KMO measure of sampling adequacy (MSA) value is very high, 0.897 indicating that the factor analysis is appropriate. In other dimension, the p-value for Barlett's test for this study indicated 0.000 for all variables which was perfectly significant as $(\mathrm{p}<.05)$ (refer to Table 3 ) 
Table 3: KMO and Bartlett's test

\begin{tabular}{lcc} 
Kaiser-Meyer-Olkin Measure of Sampling Adequacy & $\mathbf{8 9 7}$ \\
\hline Bartlett's Test of Sphericity & Approx. Chi-Square & 5657.881 \\
& df & 120 \\
& Sig. & .000 \\
\hline
\end{tabular}

Table 4 shows factor analysis results. Communalities indicate the degree to which the factors explain the variance of the variables. All items had communality values exceeding 0.50 and thus had a sufficient level of explanation.

\begin{tabular}{|c|c|c|c|c|}
\hline & LK & RD & $\mathrm{CV}$ & RE \\
\hline LK1 & .791 & & & \\
\hline LK2 & .765 & & & \\
\hline LK3 & .634 & & & \\
\hline LK4 & .615 & & & \\
\hline RDC1 & & .800 & & \\
\hline RDC2 & & .790 & & \\
\hline RDC3 & & .767 & & \\
\hline RDC4 & & .614 & & \\
\hline CV1 & & & 811 & \\
\hline CV2 & & & .737 & \\
\hline CV3 & & & .598 & \\
\hline CV4 & & & .505 & \\
\hline REC1 & & & & .786 \\
\hline REC2 & & & & .649 \\
\hline REC3 & & & & .617 \\
\hline REC4 & & & & .520 \\
\hline \% of Variance (69.767) & 48.280 & 7.863 & 6.996 & 6.628 \\
\hline Keiser Meyer Olkin Measure & & & & 0.897 \\
\hline Bartlett's Test & & & & 0.000 \\
\hline
\end{tabular}

\section{iii. Confirmatory Factor Analysis (CFA)}

A CFA is performed on data from 543 respondents collected through an analysis of moment structures (AMOS) version 20. In modeling the structural model, the study assessed the measurement model for unidimensionality, validity and reliability requirements (Anderson \& Gerbing, 1982; Hair, 2010; Kline, 2015). The model and summary assessment for fitness indexes of the study for the latent variable is presented in Figure 1 and Table 5 respectively.

\section{Figure 1: Measurement model to examine discriminant validity for latent constructs}

Fitness Indexes ChiSq $=8.338$

$$
\mathrm{Df}=2
$$

$\mathrm{GFI}=0.992$

$\mathrm{CFI}=0.988$

RMSEA $=0.077$

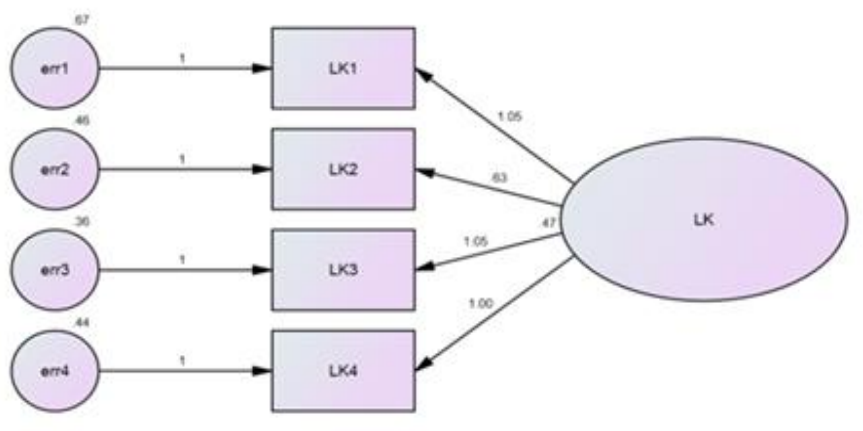


Table 5: The summary of fitness for the measurement model of exogenous constructs

\begin{tabular}{|c|c|c|c|c|c|}
\hline Name of Category & $\begin{array}{c}\text { Name of } \\
\text { index }\end{array}$ & Level of Acceptance & $\begin{array}{l}\text { Index } \\
\text { Value }\end{array}$ & Comments & \\
\hline \multirow[t]{2}{*}{ 1. Absolute fit } & RMSEA & $0.05<$ RMSEA $<0.1$ & .077 & $\begin{array}{l}\text { The requirement } \\
\text { achieved }\end{array}$ & level is \\
\hline & GFI & $\mathrm{GFI}>0.90$ & .992 & $\begin{array}{l}\text { The requirement } \\
\text { achieved }\end{array}$ & level is \\
\hline 2. Incremental fit & CFI & $\mathrm{CFI}>0.90$ & .988 & $\begin{array}{l}\text { The requirement } \\
\text { achieved }\end{array}$ & level is \\
\hline 3. Parsimoniouos fit & Chisq/df & Chi Square $/ \mathrm{df}<5.0$ & 4.169 & $\begin{array}{l}\text { The requirement } \\
\text { achieved }\end{array}$ & level is \\
\hline
\end{tabular}

\section{iv. $\quad$ Predictor of Tawhidic paradigm}

For determining the predictors, Tawhidic paradigm is used as dependent variable while legal knowledge is used as the independent variable. In the regression output via Enter Method as shown in Table 3, $\mathrm{R}$ is the correlation coefficient (.879) and the adjusted R square in the Model Summary shows that the model with the inclusion of the variable (legal knowledge) collectively explains for $77 \%$ of the variance in the Tawhidic paradigm. $\mathrm{R}$ square ranges from the value of 0 to 1 which implies that there is a linear relationship between the Tawhidic paradigm and legal knowledge.

\begin{tabular}{|c|c|c|c|c|c|c|c|c|c|}
\hline \multirow[t]{2}{*}{ Model } & \multirow[t]{2}{*}{$\mathbf{R}$} & \multirow{2}{*}{$\begin{array}{c}\mathbf{R} \\
\text { Square }\end{array}$} & \multirow{2}{*}{$\begin{array}{l}\text { Adjusted } \\
\text { R Square }\end{array}$} & \multirow{2}{*}{$\begin{array}{l}\text { Std. Error } \\
\text { of the } \\
\text { Estimate }\end{array}$} & \multicolumn{5}{|c|}{ Change Statistics } \\
\hline & & & & & $\begin{array}{c}\text { R Square } \\
\text { Change }\end{array}$ & F Change & df1 & df2 & $\begin{array}{c}\text { Sig. F } \\
\text { Change }\end{array}$ \\
\hline 1 & $.879^{a}$ & .772 & .771 & .28884 & .772 & 1829.704 & 1 & 541 & .000 \\
\hline
\end{tabular}

a. Predictors: (Constant), LK_Mean

\section{v. Mediation factors in resilient entrepreneurs}

This study used SEM to determine the role of mediating variables on resilient entrepreneurs within an independent-dependent relationship. Tawhidic paradigm is used a mediating factors in a causal between legal knowledge and entrepreneur with resilient characteristics.

The conception of Tawhidic paradigm mediates against resilient entrepreneurs is depict in Figure 1. According to Baron \& Kenny (1986), partial mediation occur when there is a direct effect of the mediator construct $M$ accounts for a significant amount of variance in $Y$ but $c$ remains significant. If c remains significant but differs in sign from the $0 \mathrm{Y}$, then mediation with suppression is evident (see Fig. 2).

\section{Figure 2: Conceptual Basis of Mediation}

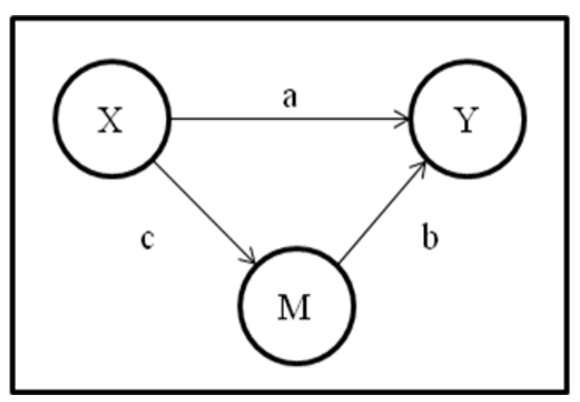

The standard coefficient or beta regression weights in Figure 2 demonstrate that when the practice of Tawhidic paradigm is present, the weight between legal knowledge to Tawhidic paradigm is .73. In contrast, the weight between Tawhidic paradigm and resilient entrepreneur is .63 while the weight between legal knowledge to resilient entrepreneur .03. To confirm whether the Tawhidic paradigm mediates between legal knowledge and resilient entrepreneurs, the study examined the standard coefficient, or beta regression weights, between the factors.

Figure 2 shows the standardized regression weight and its significance for each path. The results show that each path is significant. In testing the standardized coefficient, or beta regression between the indirect and indirect values, the analysis shows that the indirect effect is $0.46(0.73 \mathrm{x}$ 0.63). On the other hand, the direct effect between entrepreneur's curriculum and resilient entrepreneur is 0.03 . Therefore, this indicates that there is a mediation effect between the Tawhidic paradigm and resilient entrepreneur. The indirect paths between LK to TP and TP to RE are significant; indicating that the Tawhidic paradigm mediates between legal knowledge and resilient 
entrepreneur. However, to confirm whether Tawhidic paradigm is partially or completely mediates between legal knowledge and resilient entrepreneur, standard regression weight is measured in this study.

It was reported from standard regression weight that LK to RE is not significant with a pvalue of .625 (see Tab. 7). Thus, this indicates that the result did not supported the hypothesis, which entails that Tawhidic paradigm is completely mediates between legal knowledge and resilient entrepreneur (Baron \& Kenny, 1986).

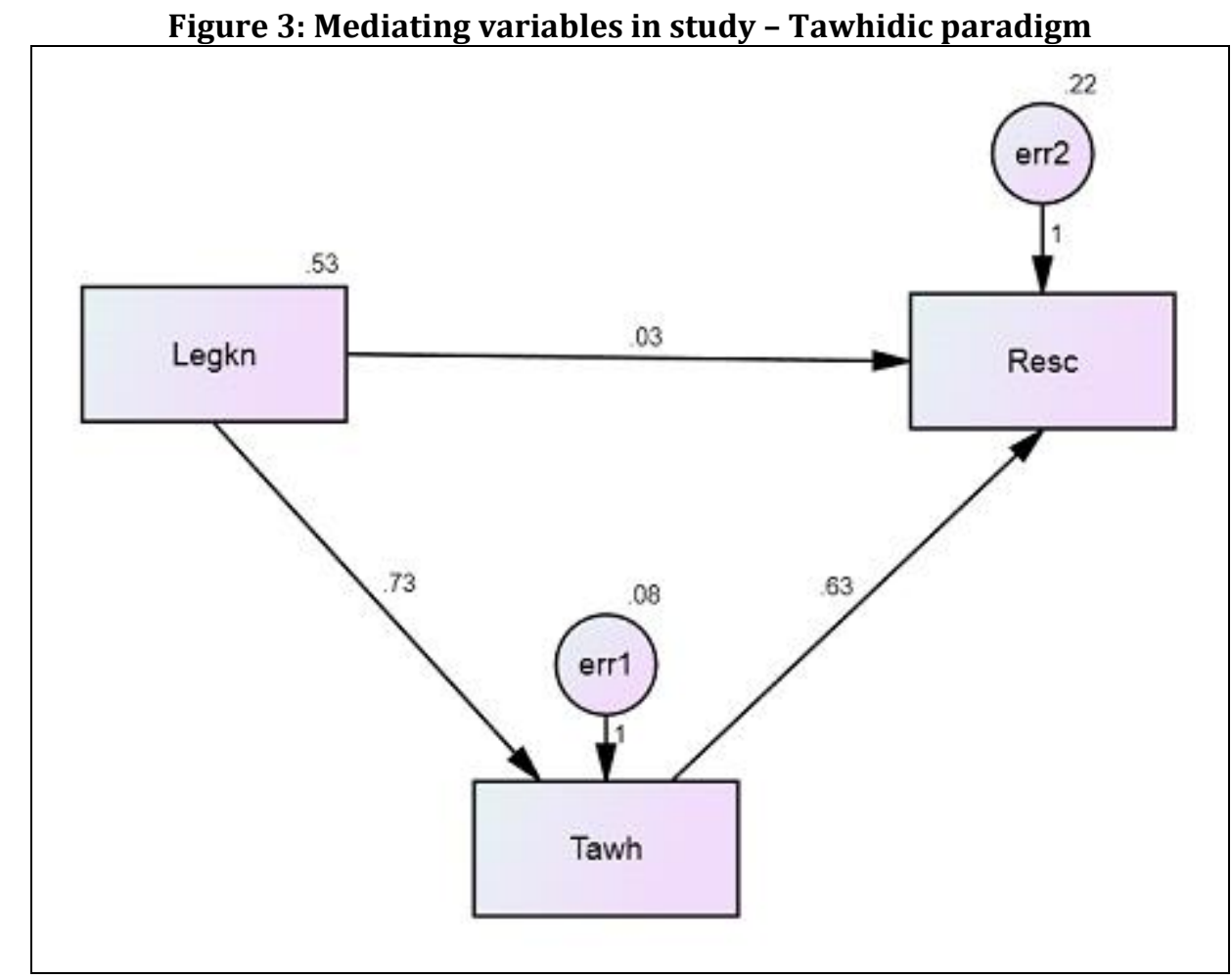

\begin{tabular}{|c|c|c|c|c|c|c|c|}
\hline & & & Estimate & S.E. & C.R. & $\mathbf{P}$ & Label \\
\hline TP_Mean & $<---$ & LK_Mean & .728 & .017 & 42.815 & $* * *$ & par_1 \\
\hline RE_Mean & $<---$ & TP_Mean & .633 & .070 & 9.083 & $* * *$ & par_2 \\
\hline RE_Mean & $<---$ & LK_Mean & .028 & .058 & .488 & .625 & par_3 \\
\hline
\end{tabular}

\section{Conclusions}

This study developed and empirically tested a model that shows better understanding of the relationship between legal knowledge and the character of resilient entrepreneur. In answering the research questions, the component of legal knowledge is investigated over entrepreneur's with resilient character. To link between these variables, this study proposed the principles of Tawhidic paradigm as a mediation factors. Generally, the result entails an analysis that explains the significances of each hypothesis.

All in all, Table 4 summarizes the hypothesis results of mediation test for the study.

\begin{tabular}{|c|c|c|c|}
\hline Hypothesis Statement of Path Analysis & Estimate & P-Value & $\begin{array}{l}\text { Results on } \\
\text { Hypothesis }\end{array}$ \\
\hline $\begin{array}{l}\text { H1: Legal knowledge has significant effect on } \\
\text { Tawhidic paradigm }\end{array}$ & 0.728 & *** & Significant \\
\hline $\begin{array}{l}\text { H2: Tawhidic paradigm has significant effect on resilient } \\
\text { entrepreneur }\end{array}$ & 0.633 & *** & Significant \\
\hline $\begin{array}{l}\text { H3: Legal knowledge has significant effect on } \\
\text { resilient entrepreneur }\end{array}$ & 0.028 & .625 & Not Significant \\
\hline
\end{tabular}

Notes. ${ }^{* * *}$ p-value $<0.01 ;{ }^{* *}$ p-value $<0.05$; $^{*}$ p-value $<0.10$ 
It is therefore concluded that the practices of legal knowledge is important in shaping entrepreneur with resilient character with the existence of Tawhidic paradigm as mediator between these variables.

\section{Implication}

The findings left important implication to academics, entrepreneurs and globalization. Notwithstanding, positive influence in Islamic concept and ideology from Tawhidic paradigm emphasizing constructive way towards achieving social responsibilities to the nation and country.

\section{Limitation}

The study acknowledges a number of limitations. The study only screened Malaysian entrepreneurs with regards to its curriculum syllabus. Another limitation is the study did not mention on the years involved in business where the level of experiences may have affected in their entrepreneurship skills and decision making. Also the study did not indicate the extent to which the law and regulation affected in the operation and practices. The outcome can thus consider as a standard for further research.

\section{Future studies}

Future study should focus to curriculum at other country with larger samples. Moreover, future study can seek to explore on years of entrepreneur's dealing with business to screen their abilities in managing and organizing business. Finally, future studies can conduct comparative analysis by exploring the fundamental principle of the successful business owners on their legislative issues and constraints.

\section{Conclusion}

The hypothesis model of this study fits well with the data structure. It proves that the implication of Tawhidic paradigm towards legal knowledge is generally successful in developing entrepreneur with resilient characteristics. It is therefore concluded that legal knowledge, Tawhidic paradigm and resilient entrepreneur had resulted in effective and significant outcomes of the desired system from learners perspective.

\section{Appendix A. Supplementary material}

Supplementary data associated with this article can be found, in the online version, at https://doi.org/10.14254/jems.2019.4-2.3

\section{Funding}

The authors received no direct funding for this research.

\section{Citation information}

Anor Salim, F. A., Maidin, A. J., Mhd Sarif, S., \& Zainudin, D. (2019). Developing entrepreneurship training curriculum based on Tawhidic paradigm and legal principles: A case study of Malaysia. Economics, Management and Sustainability, 4(2), 30-39. doi:10.14254/jems.2019.4-2.3.

\section{References}

al Faruqi, I. R. (1992). Al Tawhid: its implications for thought and life. Issues in Islamic thought.

Al Idrus, S. (2013). Entrepreneurship course in State Islamic Higher Educations (SIHEs) of East Java: a learning strategy perspective. International Journal of Academic Research, 5(3), 235239. https://doi.org/10.7813/2075-4124.2013/5-3/B.36

Ali, M. Y. (2006). Al-Tawhid and its effects on man's life. Jurnal Usuluddin, 23, 1-34.

Baron, R. M., \& Kenny, D. A. (1986). Baron \& Kenny, 1986. Journal of Personality and Social Psychology, 51, 1173-82. Retrieved from http://www.ncbi.nlm.nih.gov/pubmed/3806354

Bash, E. (2015). Entrepreneurship, Religion, And Business Ethics. PhD Proposal, 1(11), 59-69. https://doi.org/10.1017/CB09781107415324.004

Becker, K., Hauser, C., \& Kronthaler, F. (2013). Fostering management education to deter corruption: What do students know about corruption and its legal consequences? Crime, Law and Social Change, 60(2), 227-240. https://doi.org/10.1007/s10611-013-9448-8

Choudhury, M. A. (2014). Epistemology and its Applications: Economics, Finance, Science, and Society, 440. 
Cooney, T. M. (2012). Entrepreneurship Skills for Growth-Orientated Businesses. Denish Business Authority, $\quad$ (November). Retrieved from http://www.oecd.org/cfe/leed/Cooney_entrepreneurship_skills_HGF.pdf

Gümüsay, A. A. (2014). Entrepreneurship from an Islamic Perspective. Journal of Business Ethics. https://doi.org/10.1007/s10551-014-2223-7

Hashim, R. (2014a). Higher education curriculum development for islamization of knowledge. Islamic Economics Education in Southeast Asian Universities.

Hunter, M. (2014b). Entrepreneurship as a means to create Islamic Economy developed through a " bottom up," rather than a " top down " approach. The current poverty and unemployment levels of the Ummah ( World Muslim community) are briefly outlined. The paper then postul, 9(1), 75-100.

Kozlinska, I. (2011). Contemporary approaches to entrepreneurship education Inna Kozlinska. Journal of Business Management, (4), 205-220.

Pache, A.-C., \& Chowdhury, I. (2012). Social Entrepreneurs as Institutionally Embedded Entrepreneurs: Toward a New Model of Social Entrepreneurship Education. Academy of Management Learning \& Education, 11(3), 494-510. https://doi.org/10.5465/amle.2011.0019

Qardawi, Y. (2007). Al-Halal wa-al-haram fi al-Islam (The lawful and the prohibited in Islam). AlQahirah : Maktabat Wahbah.

Rengiah, P. (2013). Effectiveness of entrepreneurship education in developing entrepreneurial intentions among Malaysian university students Effectiveness of Entrepreneurship Education in Developing Entrepreneurial Intentions among Malaysian University Students.

Serafimovska, H., \& Sotiroski, L. (2014). Implications of the legal framework for the development of entrepreneurship. International Review of Social Sciences and Humanities, 7(1), 263-273.

Suhaimi, Y. I., \& Sarif, M. (2011). The role of Tawhidic paradigm in the transformation of management system. Prosiding Seminar Transformasi Sistem Pengurusan Islam Di Malaysia, 127-147.

Tlaiss, H. A. (2014). How Islamic business ethics impact women entrepreneurs: insights from four Arab Middle Eastern Countries. Journal of Business Ethics. https://doi.org/10.1007/s10551014-2138-3

Weber, J. W., \& Englehart, S. W. (2011a). Enhancing business education through integrated curriculum delivery. Journal of Management Development, 30(6), 558-568. https://doi.org/10.1108/02621711111135161

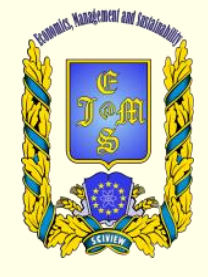

() 2016-2019, Economics, Management and Sustainability. All rights reserved.

This open access article is distributed under a Creative Commons Attribution (CC-BY) 4.0 license.

You are free to:

Share - copy and redistribute the material in any medium or format Adapt - remix, transform, and build upon the material for any

purpose, even commercially.

The licensor cannot revoke these freedoms as long as you follow the license terms.

Under the following terms:

Attribution - You must give appropriate credit, provide a link to the license, and indicate if changes were made.

You may do so in any reasonable manner, but not in any way that suggests the licensor endorses you or your use.

No additional restrictions

You may not apply legal terms or technological measures that legally restrict others from doing anything the license permits.

Economics, Management and Sustainability (ISSN: 2520-6303) is published by Scientific Publishing House "CSR",

Poland, EU and Scientific Publishing House "SciView", Poland

Publishing with JEMS ensures:

- Immediate, universal access to your article on publication

- High visibility and discoverability via the JEMS website

- Rapid publication

- Guaranteed legacy preservation of your article

- Discounts and waivers for authors in developing regions

Submit your manuscript to a JEMS at http://jems.sciview.net or submit.jems@sciview.net

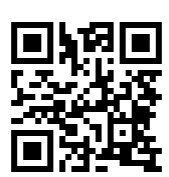

